\title{
A COMPARISON OF ANTIGENICITIES OF HYDROLYSATE AND PEPTONE TETANUS TOXOIDS IN THE GUINEA PIG ${ }^{1}$
}

\author{
By J. HOWARD MUELLER, LEAH R. SEIDMAN, and PAULINE A. MilleR \\ (From the Department of Bacteriology and Immunology, Harvard Medical School and School \\ of Public Health, Boston)
}

(Received for publication November 12, 1942)

The resistance of the animal body to the injury caused by those bacterial agents which produce powerful exotoxins is commonly held to be the best understood of the various immune reactions. The toxins themselves, entirely free from the presence of the bacteria which produce them, are capable of eliciting all of the symptoms of the natural disease, and, as in the disease itself, death or recovery may ensue according to the quantity of toxin administered. Further, these toxins, being antigens by definition, will, under suitable conditions, stimulate the production in the body of antitoxins capable of neutralizing specifically the ability of the same toxins to cause injury, - a neutralization which takes place in the test tube with almost mathematical precision and with the stoichiometric relationships of other chemical reactions. The toxins can be altered chemically, as for example by formalin, to a degree resulting in loss of ability to injure the body, while they still retain the original property of stimulating antibody production against the unaltered toxin. This last property provides the Public Health official and the physician with some of the most useful of tools for the prevention of disease, the practical value of which is now attested beyond a reasonable doubt.

It is a remarkable fact, however, that within this skeleton of definite information, there exists a mass of tradition in regard to certain details, accumulated over a period of many years, but founded either in uncontrolled experiment or in faulty observation. Many of these beliefs are held with a tenacity reminiscent of superstition, and are frequently responsible for actively retarding sound experimental advance.

Chief among these are the various dicta surrounding the laboratory preparation of toxins. For many years a perpetual source of difficulty to producers, certain statements in connection with

\footnotetext{
1 Aided by a grant from the Commonwealth Fund.
}

this process have been made so often, and with such great authority by so many workers that the absence of experimental support is no longer a source of concern. It would be simple to enumerate several of these rather fanciful beliefs, such as the one that potent toxin cannot be produced in summer,-probably explainable by the fact that hot weather is not conducive to human endeavor. The only one with which we propose to deal in this communication, however, is the old tradition that toxin cannot be produced without peptone, and the more recently drawn corollary, even if it can be produced without peptone, it is no good.

The former statement had become so ingrained in the minds of all bacteriologists, up to a few years ago, that the mere suggestion that diphtheria toxin, for example, might be obtained on a chemically defined medium was considered ridiculous. Peptone had always been found necessary; therefore, it was essential. Directing attention to the fact that growth of the organism had never been obtained without peptone resulted only in further statements that growth and toxin did not parallel each other (which is true) and that even if it were possible to grow the diphtheria bacillus on a peptone-free medium, no toxin would be obtained. Through the fortunate combination of Pappenheimer's (1) work on toxin, and experiments reported from this laboratory on growth (2), it was eventually possible to correct these erroneous impressions, and to demonstrate clearly that diphtheria toxin was a metabolic product of the growth of the bacteria under certain chemically controlled conditions (3).

Almost inevitably, then, the ability of the toxin, produced in this unorthodox manner, to behave like ordinary toxin was questioned. In particular, the competence of toxoid prepared from it to behave as an effective antigen was considered extremely doubtful. Even the fact that in toxicity and in antitoxin combining power it was considerably superior to the average material previously 
available, was held to be a disadvantage. Every manufacurer had seen toxin of an extremely low grade of potency produce antitoxin of astronomical proportions in horses, - or at least in one horse, whereas stronger toxins had often given poor results. Therefore, it was argued, since hydrolysate diphtheria toxin was relatively powerful, it would be a poor antigen. The general line of reasoning apparently questioned the fact that the toxin (or toxoid) was itself the antigen and suggested that the property of antigenicity resided primarily in some substance other than the specific poison.

Since there was no great urgency connected with the establishment of the inaccuracy of such a belief, as far as diphtheria toxoid was concerned, there seemed to be no point in carrying out elaborate experiments to establish the facts. The so-called "hydrolysate" toxoid has gradually come into production and use in certain localities, and there has been no evidence, so far as the writers are aware, of any lack of efficacy.

More important at the present time is the fact that the identical situation has now been transferred to the problem of tetanus toxoid. Employed on a tremendous scale for military immunization, its initial preparation on the traditional media containing Witte's peptone has had to be modified because of the presence, in that brand of peptone, at any rate, of a substance inducing severe anaphylaxis in certain individuals (4 to 6). Other varieties of peptone are still considered admissable, largely because no serious accidents have thus far been reported following their use. By their very nature as large fragments of protein, containing various enzyme residues and complex tissue components, their widespread use in man might well be avoided, provided the desired end may be reached without them.

These considerations have persuaded the writers to attempt the production on peptone-free media of tetanus toxin for conversion to toxoid for human use. A measure of success has attended these efforts ( 7 to 9 ), and it appears at this time to be worth while reporting a series of controlled experiments, designed to compare the antigenicity of hydrolysate toxoid with that of peptone toxoid. It seems to be a matter of some urgency that the facts in connection with this matter should be determined with accuracy and the subject definitely removed from the realm of mere speculation.

It is unfortunate that there is not at this time a tetanus toxoid which has been established as a standard in the United States. Since, however, all tetanus toxoid on the market or supplied to the military forces has been check tested at the Division of Biologics Control of the National Institute of Health and has been found to pass their minimum requirements, it would appear that specimens which have been distributed by a number of commercial producers to the trade or to the Army should constitute a reasonable standard with which a series of hydrolysate toxoids might be compared.

Proceeding on this assumption, we have obtained a number of lots of tetanus toxoid, representing products of several manufacturers, through the courtesy of the Office of the Surgeon General of the Army. The antigenicity of these toxoids

TABLE I

\begin{tabular}{|c|c|c|c|}
\hline $\begin{array}{c}\text { Guinea } \\
\text { pig }\end{array}$ & Toxoid used & Serum titer & Results of toxin injection \\
\hline & & $\begin{array}{l}\text { Units anti- } \\
\text { loxin per cc. }\end{array}$ & \\
\hline $\begin{array}{l}950 \\
951 \\
952 \\
953 \\
954 \\
955\end{array}$ & $\begin{array}{l}\text { Commercial A } \\
\text { Commercial A } \\
\text { Commercial A } \\
\text { Commercial A } \\
\text { Commercial A } \\
\text { Commercial A }\end{array}$ & \begin{tabular}{ll|}
$>1.0$ & $<2.5$ \\
$>2.5$ & $<5.0$ \\
$>0.25$ & $<0.5$ \\
$>0.25$ & $<0.5$ \\
$>2.5$ & $<5.0$ \\
$>0.1$ & $<0.25$
\end{tabular} & $\begin{array}{l}\text { No symptoms } \\
\text { No symptoms } \\
\text { No symptoms } \\
\text { No symptoms } \\
\text { (Killed in bleeding) } \\
\text { Moderate symptoms, sur- } \\
\text { vived }\end{array}$ \\
\hline 914 & Commercial B & $>0.25<0.5$ & Moderate symptoms, sur- \\
\hline $\begin{array}{l}915 \\
916 \\
917 \\
918\end{array}$ & $\begin{array}{l}\text { Commercial B } \\
\text { Commercial B } \\
\text { Commercial B } \\
\text { Commercial B }\end{array}$ & $\begin{array}{ll}>0.5 & <1.0 \\
>0.1 & <0.25 \\
>0.01 & <0.1\end{array}$ & $\begin{array}{l}\text { No symptoms } \\
\text { Marked symptoms, survived } \\
\text { No symptoms } \\
\text { Moderate symptoms, sur- }\end{array}$ \\
\hline 919 & Commercial B & 2.5 & No symptoms \\
\hline $\begin{array}{l}908 \\
909\end{array}$ & $\begin{array}{l}\text { Commercial C } \\
\text { Commercial C }\end{array}$ & $>0.1^{1.0}<0.25$ & $\begin{array}{l}\text { No symptoms } \\
\text { Moderate symptoms, sur- }\end{array}$ \\
\hline 910 & Commercial C & $>1.0 \quad<2.5$ & $\begin{array}{l}\text { vived } \\
\text { Moderate symptoms, sur- }\end{array}$ \\
\hline $\begin{array}{l}911 \\
912 \\
913\end{array}$ & $\begin{array}{l}\text { Commercial C } \\
\text { Commercial Č } \\
\text { Commercial C }\end{array}$ & $\begin{array}{ll}>1.0 & <2.5 \\
>0.1 & <0.25 \\
>0.25 & <0.5\end{array}$ & $\begin{array}{l}\text { No symptoms } \\
\text { Slight symptoms, survived } \\
\text { No symptoms }\end{array}$ \\
\hline $\begin{array}{l}920 \\
921 \\
922 \\
923 \\
924 \\
925\end{array}$ & $\begin{array}{l}\text { Commercial D } \\
\text { Commercial D } \\
\text { Commercial D } \\
\text { Commercial D } \\
\text { Commercial D } \\
\text { Commercial D }\end{array}$ & $\begin{array}{|ll|}>0.1 & 0.25 \\
>2.5 & 2.5<0.25 \\
>1.0 & 0.01<5.0 \\
<2.5\end{array}$ & $\begin{array}{l}\text { Slight symptoms, survived } \\
\text { No symptoms } \\
\text { No symptoms } \\
\text { No symptoms } \\
\text { No symptoms } \\
\text { No symptoms }\end{array}$ \\
\hline $\begin{array}{l}926 \\
927 \\
928 \\
929\end{array}$ & $\begin{array}{l}\text { Commercial } \mathbf{E} \\
\text { Commercial } \\
\text { Commercial } \\
\mathbf{E} \\
\text { Commercial }\end{array}$ & $\begin{array}{ll}>2.5 & <5.0 \\
>0.25 & <0.5 \\
>0.25 & <0.5 \\
>0.01 & <0.1\end{array}$ & $\begin{array}{l}\text { No symptoms } \\
\text { No symptoms } \\
\text { No symptoms } \\
\text { Moderate symptoms, sur- }\end{array}$ \\
\hline $\begin{array}{l}930 \\
931\end{array}$ & $\begin{array}{l}\text { Commercial } \mathbf{E} \\
\text { Commercial } \mathbf{E}\end{array}$ & $\begin{array}{ll}>0.25 & <0.5 \\
>0.1 & <0.25\end{array}$ & $\begin{array}{l}\text { No symptoms } \\
\text { No symptoms }\end{array}$ \\
\hline $\begin{array}{l}944 \\
945 \\
946 \\
947 \\
948 \\
949\end{array}$ & $\begin{array}{l}\text { Commercial F } \\
\text { Commercial F } \\
\text { Commercial F } \\
\text { Commercial F } \\
\text { Commercial F } \\
\text { Commercial F }\end{array}$ & $\begin{array}{ll}>0.001 & <0.01 \\
>0.001 & <0.01 \\
>0.001 & <0.01 \\
>0.25 & 0.01 \\
>0.25 & <0.5 \\
>0.25 & <0.5\end{array} \mid$ & $\begin{array}{l}\text { Severe symptoms, survived } \\
\text { Died, tetanus, second day } \\
\text { Died, tetanus, fourth day } \\
\text { Severe symptoms, survived } \\
\text { Slight symptoms, survived } \\
\text { No symptoms }\end{array}$ \\
\hline
\end{tabular}


TABLE II

\begin{tabular}{|c|c|c|c|c|}
\hline $\begin{array}{l}\text { Guinea } \\
\text { pig }\end{array}$ & Toxoid used & \multicolumn{2}{|c|}{ Serum titer } & $\begin{array}{l}\text { ts of toxin } \\
\text { jection }\end{array}$ \\
\hline & & \multicolumn{2}{|c|}{$\begin{array}{l}\text { units anti- } \\
\text { toxin per cc. }\end{array}$} & \multirow{5}{*}{$\begin{array}{l}\text { Moderate symptoms, } \\
\text { survived } \\
\text { Moderate symptoms, } \\
\text { survived } \\
\text { Died, tetanus, second } \\
\text { day } \\
\text { No symptoms } \\
\text { No symptoms } \\
\text { Slight 8ymptoms, sur- } \\
\text { vived }\end{array}$} \\
\hline 871 & Hydrolysate $\mathbf{Z}$ & $>0.1$ & $<0.25$ & \\
\hline 872 & Hydrolysate $\mathbf{Z}$ & $>0.001$ & $<0.01$ & \\
\hline 873 & Hydrolysate $\mathbf{Z}$ & \multicolumn{2}{|c|}{0.001} & \\
\hline $\begin{array}{l}874 \\
875 \\
876\end{array}$ & $\begin{array}{l}\text { Hydrolysate } \mathbf{Z} \\
\text { Hydrolysate } \mathbf{Z} \\
\text { Hydrolysate } \mathbf{Z}\end{array}$ & $\begin{array}{l}>0.01 \\
>0.25 \\
0.01\end{array}$ & $<0.1$ & \\
\hline $\begin{array}{l}877 \\
878 \\
879 \\
880 \\
881\end{array}$ & $\begin{array}{l}\text { Hydrolysate AO } \\
\text { Hydrolysate AO } \\
\text { Hydrolysate AO } \\
\text { Hydrolysate AO } \\
\text { Hydrolysate AO }\end{array}$ & $\begin{array}{l}>0.25 \\
>0.5 \\
>0.25 \\
0.005\end{array}$ & $\begin{array}{l}<0.5 \\
<0.5 \\
<0.25\end{array}$ & $\begin{array}{l}\text { No symptoms } \\
\text { No symptoms } \\
\text { No symptoms } \\
\text { No symptoms } \\
\text { Died, tetanus, seventh }\end{array}$ \\
\hline 882 & Hydrolysate AO & $>0.1$ & $<0.25$ & No symptoms \\
\hline 855 & Hydrolysate $A Q$ & 0.5 & & Slight symptoms, sur- \\
\hline 856 & Hydrolysate AQ & 0.5 & & $\begin{array}{l}\text { Slight symptoms, sur- } \\
\text { vived }\end{array}$ \\
\hline 857 & Hydrolysate AQ & $>0.25$ & $<0.5$ & Slight symptoms, sur- \\
\hline 858 & Hydrolysate AQ & $>0.001$ & $<0.005$ & Moderate symptoms, \\
\hline $\begin{array}{l}859 \\
860\end{array}$ & $\begin{array}{l}\text { Hydrolysate AQ } \\
\text { Hydrolysate AQ }\end{array}$ & $\begin{array}{l}0.5 \\
0.001\end{array}$ & & $\begin{array}{l}\text { No symptoms } \\
\text { Died, tetanus, second } \\
\text { day }\end{array}$ \\
\hline 800 & Hydrolysate AT & $>0.01$ & $<0.1$ & Slight symptoms, sur- \\
\hline $\begin{array}{l}801 \\
802 \\
803 \\
804 \\
805\end{array}$ & $\begin{array}{l}\text { Hydrolysate AT } \\
\text { Hydrolysate AT } \\
\text { Hydrolysate AT } \\
\text { Hydrolysate AT } \\
\text { Hydrolysate AT }\end{array}$ & $\begin{array}{c}>0.25 \\
0.01 \\
>0.25 \\
0.005 \\
0.25\end{array}$ & $\begin{array}{l}<0.5 \\
<0.5\end{array}$ & $\begin{array}{l}\text { No symptoms } \\
\text { No symptoms } \\
\text { (Killed in bleeding) } \\
\text { No symptoms } \\
\text { No symptoms }\end{array}$ \\
\hline 788 & Hydrolysate AV & 0.25 & & Slight symptoms, sur- \\
\hline $\begin{array}{l}789 \\
790\end{array}$ & $\begin{array}{l}\text { Hydrolysate AV } \\
\text { Hydrolysate AV }\end{array}$ & $>0.1^{0.001}$ & $1<0.25$ & $\begin{array}{l}\text { Died, tetanus, third day } \\
\text { Questionable symptoms, }\end{array}$ \\
\hline 791 & Hydrolysate AV & $>0.001$ & $<0.01$ & Died, tetanus, second \\
\hline $\begin{array}{l}792 \\
793\end{array}$ & $\begin{array}{l}\text { Hydrolysate AV } \\
\text { Hydrolysate AV }\end{array}$ & $\begin{array}{l}0.1 \\
0.25\end{array}$ & & $\begin{array}{l}\text { No symptoms } \\
\text { No symptoms }\end{array}$ \\
\hline 848 & Hydrolysate BD & 0.002 & & Severe symptoms, re- \\
\hline $\begin{array}{l}850 \\
851\end{array}$ & $\begin{array}{l}\text { Hydrolysate BD } \\
\text { Hydrolysate BD }\end{array}$ & $>0.25$ & $<0.5$ & $\begin{array}{l}\text { No symptoms } \\
\text { Moderate symptoms, re- } \\
\text { covered }\end{array}$ \\
\hline $\begin{array}{l}852 \\
853\end{array}$ & $\begin{array}{l}\text { Hydrolysate BD } \\
\text { Hydrolysate BD }\end{array}$ & $\begin{array}{l}>5.0 \\
>0.1\end{array}$ & $\begin{array}{l}<7.5 \\
<0.25\end{array}$ & $\begin{array}{l}\text { No symptoms } \\
\text { Moderate symptoms, }\end{array}$ \\
\hline 854 & Hydrolysate BD & $>0.25$ & $<0.5$ & No symptoms \\
\hline
\end{tabular}

TABLE III

Antitoxin titers of pools of sera from each lot

Commercial A 0.8 units per cc. Commercial B 0.4 units per $\mathrm{cc}$. Commercial $\mathrm{C}$ 0.5 units per $\mathrm{CC}$. Commercial D 0.6 units per $\mathrm{cc}$. Commercial E 0.5 units per $\mathrm{cc}$.

Hydrolysate $Z 0.1$ units per $c c$. Hydrolysate AO 0.3 units per $C C$. Hydrolysate AQ 0.3 units per $\mathrm{CC}$. Hydrolysate AT 0.2 units per cc. Hydrolysate AV 0.2 units per CC. Commercial F 0.1 to 0.2 units per cc. Hydrolysate BD 0.6 units per $c c$.

for guinea pigs and for man has been examined in parallel with a number of hydrolysate toxoids produced in this laboratory. The data in regard to guinea pig assay is presented herewith, while the results of human immunizations will be summarized in a separate communication.

\section{METHOD}

For a variety of reasons, the standard test method of the National Institute has not been followed. There is, at present, no really suitable and generally accepted method of appraising antigenicity. We have chosen to adopt a procedure which should give the maximum information possible from the number of animals used.

A subcutaneous injection of $1.0 \mathrm{cc}$. of toxoid was given each of a series of guinea pigs, of approximately 250 grams per pig. Six or more animals were injected from each batch of toxoid to be examined. Included were toxoids from 6 different manufacturers, and 6 different lots of hydrolysate product. At the end of 6 weeks, the animals were bled from the heart, the individual sera separated and titrated for the antitoxin level. An occasional pig died as a result of the bleeding, but all others were injected, usually 48 hours later, with a massive (1000 MLD) dose of standard tetanus toxin (National Institute Lot $\mathrm{H} 3$ ), and the subsequent presence or absence of symptoms or time of death noted. The results are tabulated in Tables I, II, and III.

\section{DISCUSSION}

An inspection of the above data shows, in the first place, the tremendous individual variations among guinea pigs in ability to respond to identical stimuli. Tetanus toxoid is reputedly a relatively poor antigen when given initially, presumably because it represents a completely new experience for the tissue cells. Evidently, in certain animals, there is almost no antitoxin produced, while in others, the response is considerable. Assuming this to be an inherent vital property, it becomes problematical to what extent the differences indicated in the tables, between the commercial toxoids $A$ and $F$, for example, demonstrate an actual dissimilarity in antigenicity of such magnitude.

If it were possible to obtain a genetically pure strain of guinea pigs with considerably greater uniformity of response, more significant comparative estimates would be possible. The only such strain now available, the so-called "Connaught," was employed in the test on hydrolysate AO quoted in the table, and in a repeat test on lot $Z$. The latter resulted in antitoxin titers of $<0.001$, $>0.001<0.01,>0.001<0.01,>2.5<5.0$, $>0.5<1.0$, and $>2.5<5.0$, with a pool of 0.5 units per cc. It is therefore apparent that these guinea pigs, also, differ in their ability to respond, and would be no more satisfactory than a mixed stock.

On the whole, as far as the results in guinea pigs go, it seems fairly obvious that there is no qualitative, and certainly very little, if any, quantitative difference in antigenic action between 
toxoids free from, and those containing, peptone. In other words, the theoretical aspect of the question, outlined in the introduction, appears to be born out. If the presence of "peptone," by which is meant relatively large, possibly non-diffusible fragments of protein, supplies and adjuvant effect on antigenicity, it must be a relatively feeble one.

The writers wish to thank Mr. William McBrearty for his technical assistance in carrying out this work.

The work described in this paper was done under a contract, recommended by the Committee on Medical Research, between the Office of Scientific Research and Development and Harvard University.

\section{BIBLIOGRAPHY}

1. Pappenheimer, A. M., Jr., Studies in diphtheria toxin production. II. Production of potent diphtheria toxin on a simple amino-acid medium. Brit. J. Exper. Path., 1936, 17, 342.
2. Mueller, J. H., Nutrition of the diphtheria bacillus. Bact. Rev., 1940, 4, 97.

3. Pappenheimer, A. M., Jr., Mueller, J. H., and Cohen, S., Production of potent diphtherial toxin on a medium of chemically defined composition. Proc. Soc. Exper. Biol. and Med., 1937, 36, 795.

4. Cooke, R. A., Hampton, S., Sherman, W. B., and Stull, A., Allergy induced by immunization with tetanus toxoid. J. A. M. A., 1940, 114, 1854.

5. Whittingham, H. E., Anaphylaxis following administration of tetanus toxoid. Brit. M. J., 1940, 1, 292.

6. Parish, H. J., and Oakley, C. L., Anaphylaxis after injection of tetanus toxoid. Brit. M. J., 1940, 1, 294.

7. Mueller, J. H., Schoenbach, E. B., Jezukawicz, J. J., and Miller, P. A., Production of tetanus toxin on peptone-free media. J. Clin. Invest., 1943, 22, 315.

8. Schoenbach, E. B., Jezukawicz, J. J., and Mueller, J. $\mathrm{H}$., Conversion of hydrolysate tetanus toxin to toxoid. J. Clin. Invest., 1943, 22, 319.

9. Mueller, J. H., and Miller, P. A., Large scale production of tetanus toxin on a peptone-free medium. J. Immunol. (In press.) 